HortSCIENCE 26(2):188-190. 1991.

\title{
Variation in Growth, Spur Density, and Yield of 'MacSpur McIntosh'
}

\author{
C.G. Embree' and K.B. McRae \\ Agriculture Canada, Research Center, Kentville, N.S. B4N 1J5, Canada
}

E.N. Estabrooks ${ }^{3}$

Agriculture Canada, Research Station, Fredericton, N.B. E3B 4Z7,

Canada

C. Pratt $^{4}$

Department of Horticultural Sciences, New York State Agricultural

Experiment Station, Geneva, NY 14456-0462

Additional index words. Malus $\times$ domestics, apple mutants, 'McIntosh' sports

\begin{abstract}
Vegetative and fruiting characteristics were measured for a spur mutant of 'McIntosh' apple (Malus $\times$ domestics Borkh.). Nine-year-old 'MacSpur' trees in an orchard in New Brunswick, Canada, were grouped according to three degrees of spurriness. Reduced terminal growth, fewer limbs per tree, more flowering spurs per unit length of 2- and 3-year-old wood, less yield, and lower yield efficiency were associated with the highest degree of spurriness. The variability suggests that 'MacSpur' may be an unstable periclinal chimera.
\end{abstract}

'MacSpur McIntosh' (Greenslade strain) originated as a whole tree mutation of 'Summerland Red McIntosh' (Fisher, 1969). Although various studies have been carried out to determine and describe the unique growth and biochemical constituents of this and other 'McIntosh' mutants, reports on field performance are scarce (Looney and Lane, 1984). Variation in the habit of spur-type trees propagated vegetatively from 'McIntosh' spur sports have been reported (Forshey et al., 1987; Swales, 1981), described (Lord et al., 1983; Walsh and Miller, 1984), and recently recognized as a problem (Ferree, 1988). The objective of the present study was to measure the degree of variation in vegetative and fruiting characteristics in the 'MacSpur McIntosh' trees.

Trees of 'MacSpur McIntosh' onMM.111 rootstock (purchased from Hilltop Orchards and Nurseries, Hartford, Mich.) were planted in 1979 at a $4.3 \times 6.1-\mathrm{m}$ spacing (383 trees/ha) in a commercial orchard at St. Joseph, New Brunswick, Canada. They

Received for publication 8 Jan. 1990. The cost of publishing this paper was defrayed in part by the payment of page charges. Under postal regulations, this paper therefore must be hereby marked advertisement solely to indicate this fact.

${ }^{1}$ Research Scientist.

${ }^{2}$ Regional Statistician.

${ }^{3}$ Biologist.

${ }^{4}$ Senior Research Associate (retired). were consistent with others in the region and bloomed very heavily in 1988 . The orchard was well managed and apparently healthy. Full bloom was on 8 June 1988, and the chemical thinner Sevin was applied when mean fruit diameter was $1.25 \mathrm{~cm}$.

Before data collection, the trees were visually grouped according to three degrees of habit based on spur morphology (Lapins and Fisher, 1974) and tree form (Lord et al., 1983). These categories were nonspur (A), intermediate (B), and spurred (C). Measurements were obtained for one branch from each of the north and south sides of nine randomly selected trees in each category. Length of shoot growth was determined after the 1988 growing season, for current season's growth (1988), and for 1- (1987), 2(1986), and 3-year-old (1985) wood. Limbs per tree, at least $1 \mathrm{~m}$ in length, and the number of flowering spurs on wood produced in 1985 and 1986 were counted. To determine fruit drop, the initial number of fruit on 1985 and 1986 wood was determined within 10 days of petal fall and again just before harvest. Trunk cross-sectional area (TCA) was also calculated from trunk circumferences measured at $30 \mathrm{~cm}$. Immediately before harvest, a random sample of 50 fruits per tree was weighed and graded by color and size (data not shown).

Measurements from the north and south branches of 27 trees were combined for the analysis of variance. Although some of the 


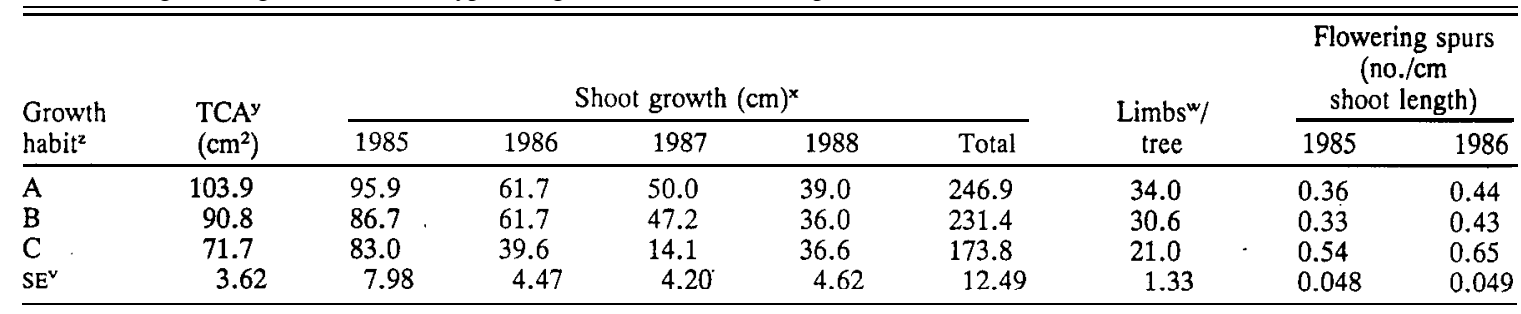

${ }^{2} \mathrm{~A}=$ nonspur; $\mathrm{B}=$ intermediate; $\mathrm{C}=$ spurred.

${ }^{y} \mathrm{TCA}=$ trunk cross-sectional area.

${ }^{\mathrm{x}}$ Growth in year given.

"Limb = branches at least $1 \mathrm{~m}$ long.

${ }^{\mathrm{v}} \mathrm{SE}=$ standard error of the mean $(\mathrm{n}=9$, df $=24)$.

Table 2. Fruiting of three types of growth habit in 'MacSpur McIntosh'/MM. 111 in New Brunswick, Canada.

\begin{tabular}{|c|c|c|c|c|c|c|c|c|c|c|}
\hline \multirow{3}{*}{$\begin{array}{l}\text { Growth } \\
\text { habit }^{2} \\
\end{array}$} & \multirow{2}{*}{\multicolumn{2}{|c|}{$\begin{array}{l}\text { Fruit drop } \\
(\%)^{y}\end{array}$}} & \multirow{2}{*}{\multicolumn{2}{|c|}{$\begin{array}{c}\text { Fruit } \\
\text { (no./spur) }\end{array}$}} & \multicolumn{4}{|c|}{ Fruit wt } & \multirow{3}{*}{$\begin{array}{c}1988 \text { Yield } \\
(\mathrm{kg} / \text { tree })\end{array}$} & \multirow{3}{*}{$\begin{array}{c}\text { Efficiency } \\
\left.\text { (kg yield/cm } \mathrm{cm}^{2} \mathrm{TCA}\right)\end{array}$} \\
\hline & & & & & \multicolumn{2}{|c|}{$\left(\mathrm{g} \cdot \mathrm{cm}^{-1} \operatorname{limb}\right)$} & \multicolumn{2}{|c|}{ (g/fruit) } & & \\
\hline & $1985^{x}$ & 1986 & 1985 & 1986 & 1985 & 1986 & 1985 & 1986 & & \\
\hline A & 58 & 40 & 1.13 & 1.34 & 13.2 & 20.2 & 88 & 79 & 79.2 & 0.77 \\
\hline B & 55 & 54 & 1.15 & 1.14 & 12.2 & 14.4 & 88 & 79 & 62.4 & 0.69 \\
\hline C & 60 & 65 & 1.47 & 1.32 & 18.3 & 19.9 & 88 & 91 & 44.5 & 0.61 \\
\hline$S E^{w}$ & 6.5 & 5.9 & 0.091 & 0.091 & 3.82 & 3.60 & 3.0 & 2.2 & 5.04 & 0.042 \\
\hline
\end{tabular}

${ }^{2} \mathrm{~A}=$ nonspur; $\mathrm{B}=$ intermediate; $\mathrm{C}=$ spurred.

based on difference between initial set and harvest.

${ }^{\mathrm{x}}$ Year of growth.

${ }^{\mathrm{w}} \mathrm{SE}=$ standard error of the mean $(\mathrm{n}=9$, df $=24)$,

variates were counts or ratios, the range of values was not sufficient to require transformation before analysis. The linear. regression on the degree of spurriness was computed and tested for significance $(P<0.05)$. Results are presented in tables of means with the standard error of the mean (SE) to indicate the precision.

Tree growth, as measured by TCA, shoot length, and the number of limbs per tree, decreased with increasing spurriness (Table 1). TCA of $\mathrm{C}$ trees compared with $\mathrm{A}$ trees was reduced by $30 \%$ in New Brunswick, in contrast to $23 \%$ in Massachusetts (Lord et al., 1983). The lower vigor in our trees may be associated with the slower growth expected in New Brunswick trees. The annual growth rate was 10.4 and $7.2 \mathrm{~cm}^{2}$ for $\mathrm{A}$ and $\mathrm{C}$ trees, compared with 16.4 and $12.6 \mathrm{~cm}^{2}$, respectively, in Massachusetts (Lord et al., 1983).

The greatly reduced terminal growth of the $\mathrm{C}$ group in 1986 and 1987 suggested that environmental factors influencing tree growth in those years affected highly spurred trees more than the others. The number of limbs in the $\mathrm{B}$ and $\mathrm{C}$ groups were $90 \%$ and $62 \%$, respectively, of that in the A group (Table $1)$. The number of flowering spurs per centimeter of limb increased as spurriness increased (Table 1). These results concur with those of Lapins and Fisher (1974) and Lord et al. (1983); who worked with 4- and 12year-old spur and nonspur 'McIntosh' trees, respectively.

The $\mathrm{C}$ group had the greatest density of flowering spurs on both 1985 and 1986 wood (Table 1). There was no significant difference between the other two groups. However, flowering spur density was higher on 1986 than on 1985 wood in all groups. The flowering spur density of 0.65 per centimeter of limb for the $\mathrm{C}$ group was much higher than the 0.30 reported by Walsh (1981) for 'MacSpur' or the 0.42 reported by West wood and Zielinski (1966) for spur-type 'Red Delicious'. However, our level of flowering spur, density in A and B groups was similar to those reported by Walsh (1981) and Westwood and Zielinski (1966) for nonspur-type trees.

Fruit drop on 1985 and 1986 wood ranged from $40 \%$ to $65 \%$ of the initial fruit set (Table 2). There were no significant differences among the groups for the 1985 wood. The 1986 wood had more drop in the $\mathrm{C}$ group than the A group, the $\mathrm{B}$ group being intermediate.

The number of fruits per spur on the 1985 wood at harvest was greatest in the $\mathrm{C}$ group (Table 2). The other two groups showed no significant differences. There were no differences among the groups on 1986 wood. Fruit weight per centimeter of limb from 1985 and 1986 wood did not differ significantly among the growth habits, but tended to be greater on the youngest fruiting wood in all three groups. Fruit size, expressed as mean weight per fruit, on the 1986 wood was largest in the $\mathrm{C}$ group. No other significant differences in size were found (Table 2).

Fruit yield increased as the degree of spurriness decreased (Table 2) and as tree size increased (Table 1), supporting earlier work (Hunter and Proctor, 1986; Lord et al., 1983). Yield efficiency ( $\mathrm{kg}$ yield $/ \mathrm{cm}^{2} \mathrm{TCA}$ ) also decreased with the degree of spurring. Fruit color was high and was not significantly influenced by the spur category (data not shown).

The data presented quantify the relationship of vegetative and fruiting characteristics to the degree of spurring invariable 'MacSpur McIntosh' trees. Group A is considered as having a standard nonspur habit and group $\mathrm{C}$ a spur-type habit, while those in the B group appeared to be intermediate. This is the second report of suspected reversion in 'MacSpur' (Lord et al., 1983). Tree reversions were also found by Embree (1984) in 'Starkspur Ultra Mac'. Two 'McIntosh' sports have been reported to show within-tree reversions from spur to standard habit, i.e., 'MacSpur' (Lord et al., 1983) and 'MorSpur' (Swales, 1981). No reversion has been recorded for the least spurry of the mutants, 'Starkspur McIntosh' (Fisher, 1969). The most compact, highly spurred 'McIntosh' spur sport, 'Wijcik', reported to have originated as a new shoot on an old limb (Fisher, 1970; Lapins, 1969; Looney and Lane, 1984), has shown no tendency of reversion, although it has not been propagated in commercial numbers.

Tree-to-tree variation in the degree of spurring and associated growth habits of three of the five 'McIntosh' spur mutants should not be attributed solely to errors in selection of scion wood, although this is possible in some cases. These variable growth habits exist in many orchards, with many planting dates, and in many locations. This study corroborates the previously reported variation in spurriness in commercial orchards. Spur mutations of 'Golden Delicious', which exhibit tree-to-tree variation or reversion to a nonspur habit in Italy (Faedi and Rosati, 1985), were suspected of being periclinal chimeras. Therefore, we suggest that 'MacSpur' is probably a periclinal chimera (Pratt, 1983, 1990). Inherent variation in the vegetative growth of 'MacSpur' trees diminishes the associated economic advantages such as closer plantings and reduced pruning costs. Additional research is needed to develop stable, compact spur-type 'McIntosh' trees for commerical high-density orchards. 


\section{Literature Cited}

Embree, C.G. 1984. Variations in tree form in an eight-year-old spur-type McIntosh planting. Fruit Notes 49:16-17.

Faedi, W. and P. Rosati. 1985. Reversion in spur clones of Delicious and Golden Delicious apple trees. Acta Hort. 159:57-61.

Ferree, D.C. 1988. Role of rootstock and spurtype scions for controlling vegetative growth of apple and peach trees. HortSciencc 23:464-467.

Fisher, D.V. 1969. Spur-type strains of McIntosh for high density planting. B.C. Fruit Growers' Assn. Quarterly Rpt. 14:3-10.

Fisher, D.V. 1970. Spur strains of McIntosh discovered in British Columbia, Canada. Fruit Var. \& Hort. Dig. 24:27-32.

Forshey, C.G., R.W. Weires, and J.R. VanKirk. 1987. Seasonal development of the leaf canopy of 'Macspur McIntosh' apple trees. HortScience 22:881-883.
Hunter, D.M. and J.T.A. Proctor. 1986. The correlation of light interception with yield and fruit color of McIntosh apple strains. Fruit Var. J. 40:79-83.

Lapins, K. 1969. Segregation of compact growth types in certain, apple seedling progenies. Can. J. Plant Sci. 49:765-768.

Lapins, K. and D. V.. Fisher. 1974. Four natural spur-type mutants of McIntosh apple. Can. J. Plant Sci. 54:359-362.

Looney, N.E. and W.D. Lane. 1984. Spur-type growth mutants of McIntosh apple: A review of their genetics, physiology and field performance. Acta Hort. 146:31-46.

Lord, W.J., R.A. Damon, and D.W. Green. 1983. Variations in growth and productivity among MacSpur apple trees, and growth comparisons between spur and nonspur McIntosh and. Delicious cultivars. Fruit Var. J. 37:95-99.
Pratt, C. 1983. Somatic selection and chimeras, p. 172-185. J.N. Moore and J. Janick (eds.). Advances in fruit breeding. Purdue Univ. Press, West Lafayette, Ind.

Pratt, C. 1990. Apple trees: Morphology and anatomy. Hort. Rev. 12:265-305.

Swales, J.E. 1981. Performance of McIntosh and Delicious strains in British Columbia. Proc. Massachusetts Fruit Growers' Assn. 87:90-98.

Walsh, C.S. 1981. A comparison of the growth and fruiting of McIntosh and Macspur apple trees. Fruit Var. J. 35:131-133.

Walsh, C.S. and A.N. Miller. 1984. Observations of the growth and vigor of spur and non-spur type apple trees. Acta Hort. 146:211-214.

Westwood, M.N. and Q.B. Zielinski. 1966. Comparative growth habit and leaf composition of a compact mutant and standard Delicious apple. Proc. Amer. Soc. Hort. Sci. 88:9-13. 